\title{
AC 2009-2409: PREPARATION AND REFLECTION: MAKING PROFESSIONAL PRACTICE EXPLICIT
}

\section{Prue Howard, Central Queensland University}

Dr Prue Howard is a senior lecturer and Convenor of the Future Engineering Education Directions (FEED) research and scholarship group at CQUniversity. She has BEng (Mech), ME in Dynamics and a Professional Doctorate in Transdiciplinary Studies. She moved to the higher education sector in 1990 after a career as a mechanical designer in industry. A love of teaching has kept her there since. Prue has received National Awards in the areas of Women in Engineering and Curriculum Innovation, as well as having received the University's Vice-Chancellor's Award for Quality Teaching and the Deans Award for Teaching Excellence twice. Since 1994 her research has centred around engineering education, resulting in significant publications and grants. A major outcome of early grants was the evidence to introduce PBL initially as a philosophy, and then as the basis for the University's Carrick Award winning engineering programs. Since then she has been involved in research in the area of Safe Design and the transdisciplinary teaching of safe design. Research areas now include the development of identity and how this can impact on student learning. 


\title{
Preparation and Reflection - Making Professional Practice Explicit
}

\begin{abstract}
The Bachelor of Engineering (Co-op) has been offered at CQUniversity, Australia, since 1994. Development of the co-operative education program recognised that real learning from the work placements would require explicit preparation for the work placement, and reflective practice after the placement. The outcome would be the ability of the students to articulate their learning, and recognise their strengths and weaknesses at any stage in the program of study.

Following the introduction of the co-op program, the faculty instituted a staged introduction of activities and processes to achieve the preparation and reflection requirements for the work placement. The changes included a move to Project Based Learning (PBL) with a partially inverted curriculum, and the introduction of a dual award, the Bachelor of Engineering(Coop)/ Diploma of Professional Practice.
\end{abstract}

PBL and an inverted curriculum was introduced in 1998, with the aim being to ensure that students were sufficiently prepared to work as junior engineers in industry at the end of their second year of study. The PBL curriculum was intended to teach students in context, with content being integrated instead of delivered in discipline silos, as well as developing a number of the professional practice skills required, such as teamwork, communication, critical thinking and problem solving.

The Diploma of Professional Practice was introduced in 2004 to make explicit the preparation for and reflection on the workplace experience. Many of the activities and outcomes addressed by the new Diploma program had been delivered by the faculty prior to this time, but the students had not been given credit, and the faculty had received no payment for the extra work.

This paper describes the programs and justifies the decisions made to offer these programs in this format.

\section{Program History}

The call for changes in Engineering Programs worldwide has been heard for decades. In the last 2 decades in Australia there have been a number of reviews of engineering education. Two of these have been supported by the Engineering profession and the Deans (IEAust ${ }^{1}$ and King ${ }^{2}$ ). The outcome is that it is well recognised that educators now need to develop graduates with attributes and abilities previously not considered core to their professional practice. As a result there has been an attempt to redefine professional engineering practice ( $\mathrm{Thom}^{3}$ ). International conferences since have called for the development of generic attributes in engineers, which encompass the multi-faceted concepts of engineering practice (Boeing Company and Rensselaer Polytechnic Institute ${ }^{4}$.

While much of this discussion was happening, some individual universities were anticipating and addressing the issues. With the aim of better preparing its graduates for the industrial work place 
of the $21^{\text {st }}$ century, CQUniversity (CQU), in Australia, introduced Co-operative Education into its Bachelor of Engineering program in 1994. The initial introduction was made without any other substantial curriculum changes. The only real pedagogical change was the introduction of distance education to deliver two courses whilst students were on their work placements. The cooperative education component consisted of two nominal six months work placements, one at the beginning of third year and the other in the second half of fourth year.

As could be expected, the introduction of Co-operative Education as discussed in Jorgensen \& Howard ${ }^{5}$, achieved only part of the aim. The faculty at the time of approving the program, recognised that a complete review of the program would be required to develop the professional of the future. Engineering graduates, to be properly prepared for the workplace still required explicit development of generic skills, such as problem solving, creativity, communication and teamwork.

\section{Faculty Review}

A number of the issues relating to the old program are identified in Jorgensen \& Howard $\left(2005^{5}\right)$. A summary of those issues is:

- Program overloaded with technical content (as technology changed, material was simply added to the program, with very little being removed)

- Students were overloaded with excessive class contact hours (29 hours per week in first year)

- High student attrition rates (up to $50 \%$ attrition from first year)

- Repeat teaching (surface learning resulted in material being forgotten as soon as the course was passed, and consequently material had to be re-taught when it was next needed)

- Students were not integrating material

During the review process it became clear that the traditional CQU (and generally Australian) engineering curricula no longer adequately prepared graduates for professional life. The curricula were still heavily analytical, even though technology had automated many analytical tasks. Self-learning and sustained learning was not strongly encouraged, even though it was an obvious strategy for coping with rapid technological advances.

The review process also highlighted fundamental problems with the traditional program structures. These included:

- the promotion of rote or surface learning by excessive course workloads and a reliance on closed book examinations

- the development of a fragmented knowledge base in traditional course units; students find it extremely difficult to integrate knowledge in a design environment, and have poor problem solving skills

- very poor understanding of professional attitudes and values amongst students.

The faculty identified that a learning environment that reflected the professional workplace and provided a meaningful context in which the fundamentals of technology and design could be 
studied, was required. Through a review of international teaching and learning in engineering, and the outcomes of a National Teaching Grant, problem-centred or project-based curricula were identified as providing the best solution. The bulk of the international education literature had for at least twenty years, agreed that project-based learning had the following advantages:

- it takes account of the way in which students learn, the learning style is active, deep and contextual

- enormous improvements in student motivation have occurred elsewhere; first year attrition rates can be as low as a few percent

- $\quad$ it develops a high level of generic and self learning skills

- it supports the integrated view that most engineers have of their profession

- $\quad$ project-based learning produces highly valued engineers in the industrial setting

The outcome of the faculty review was the proposal for significant curriculum and pedagogical changes. The review conducted in 1995/6 resulted in the development in 1997 of a Project Based Learning (PBL) philosophy incorporating a partially inverted curriculum, to complement and enhance the co-operative education model already in place. The PBL/Co-operative education Bachelor of Engineering program commenced operation in 1998.

In addition to the PBL approach to teaching, the faculty had delivered professional practice skills training, specifically designed to support the students in their co-op placements. The placements then gave the opportunity to work in industry where they could use and develop these skills. Upon their return to the academic environment, they were encouraged through reporting requirements for their work placement, to reflect upon how those issues had impacted their placement. These learning opportunities however were not formally recognised by the university, (except in the assessment of the work placement report) and were not credited towards their degree. This lack of recognition and credit was the motivation for the development of a Professional Practice program. This program replaced and extended material previously provided in the Work Placement courses of the Engineering Co-op Program.

\section{Engineering Professional Practice}

The Diploma of Professional Practice, integrated with the Project Based Learning (PBL) Bachelor of Engineering (Co-operative Education), aims to explicitly equip graduates with the knowledge, skills and attributes needed in professional practice and for professional leadership. The combined program is designed around the triple themes of intellectual, social and professional development. (James Goldston Faculty of Engineering and Physical Systems) ${ }^{6}$.

The Diploma of Professional Practice program is a generic program designed to provide students with the necessary professional practice skills to go into the work placement and the opportunity to reflect upon their experiences in the workplace. It is through this reflective process that the implicit learning from the work placement becomes explicit, assessable learning. Graduates of this dual award program have demonstrated the knowledge, skills and attitudes needed for professional engineering practice and leadership. This encompasses academic knowledge and skills with engineering discipline theory, technical expertise, personal development and professional formation. In particular this program enables specific and measurable development 
of professional engineering practice skills, employment readiness, social awareness and lifelong learning attributes.

The new program separates the professional development components previously combined with the BEng(Co-op) work placement courses and presents them in an explicit program. This explicit program provides students with due recognition of their professional practice skills. This program is now integrated with the $\mathrm{BEng}(\mathrm{Co}-\mathrm{op})$ program to form a dual award program known as Bachelor of Engineering (Co-op)/Diploma of Professional Practice (BEng(Coop)/DipProfPrac(Eng)). With the introduction of this dual award, the BEng(Co-op) is no longer offered as a stand alone program.

In 2005 the dual award program was introduced. The new structure is shown in Table 1 below.

Table 1. Bachelor of Engineering (Co-op)/Diploma of Professional Practice (Engineering) Program Structure

\begin{tabular}{|c|c|c|}
\hline YEAR & TERM 1 & TERM 2 \\
\hline \multirow{3}{*}{1} & Lecture Based Course & Lecture Based Course \\
\hline & Lecture Based Course & Lecture Based Course \\
\hline & Project Based Course & Project Based Course \\
\hline \multirow{4}{*}{2} & Lecture Based Course & Lecture Based Course \\
\hline & Lecture Based Course & Lecture Based Course \\
\hline & \multirow[b]{2}{*}{ Project Based Course } & Professional Practice Course \\
\hline & & Project Based Course \\
\hline \multirow{4}{*}{3} & \multirow{4}{*}{$\begin{array}{c}\text { Work Experience - Industry } \\
\text { Placement } \\
\text { External Study Course }\end{array}$} & Lecture Based Course \\
\hline & & Lecture Based Course \\
\hline & & Professional Practice Course \\
\hline & & Project Based Course \\
\hline \multirow{4}{*}{4} & Lecture Based Course & \multirow{4}{*}{$\begin{array}{c}\text { Work Experience - Industry } \\
\text { Placement } \\
\text { External Study Course }\end{array}$} \\
\hline & Lecture Based Course & \\
\hline & Professional Practice Course & \\
\hline & Project Based Course & \\
\hline \multirow{4}{*}{5} & Lecture Based Course & \multirow{4}{*}{ Graduation } \\
\hline & Lecture Based Course & \\
\hline & Professional Practice Course & \\
\hline & Project Based Course & \\
\hline
\end{tabular}


Whilst this appears to be an increased load for students, it formally recognises additional learning that students were, to a large extent, already undertaking previously in preparation for, and reflection after completion, of their work placements.

\section{Professional Practice Program Structure}

The structure of the Diploma of Professional Practice program element of the dual award program is as shown in Table 2 below.

Table 2 Professional Practice Element of the Co-operative Education Engineering Program

\begin{tabular}{|c|c|c|}
\hline Course & $\begin{array}{l}\text { Units } \\
\text { of } \\
\text { Credit }\end{array}$ & Comments \\
\hline $\begin{array}{l}\text { Professional Practice } \\
\text { Preparation } 1 \text { (PPP1) }\end{array}$ & 6 & $\begin{array}{l}\text { Covers resume writing, interview skills, ethics, } \\
\text { health and safety, industrial relations- prior to } 1^{\text {st }} \\
\text { work experience }\end{array}$ \\
\hline $\begin{array}{l}\text { Professional Practice Review } \\
1 \text { (PPR1) }\end{array}$ & 6 & $\begin{array}{l}\text { Covers documentation of actual work experience } \\
\text { using competency framework, formal presentation } \\
\text { of work experiences, shared reflection workshops.- } \\
\text { following } 1^{\text {st }} \text { work experience }\end{array}$ \\
\hline $\begin{array}{l}\text { Professional Practice } \\
\text { Preparation } 2(\mathrm{PPP} 2)\end{array}$ & 6 & $\begin{array}{l}\text { Covers additional engineering workplace skills } \\
\text { similar to first line supervisors course.- prior to } 2^{\text {nd }} \\
\text { work experience }\end{array}$ \\
\hline $\begin{array}{l}\text { Professional Practice Review } \\
2 \text { (PPR2) }\end{array}$ & 6 & $\begin{array}{l}\text { Covers documentation of actual work experience } \\
\text { using competency framework, formal presentation } \\
\text { of work experiences, shared reflection workshops.- } \\
\text { following } 2^{\text {nd }} \text { work experience }\end{array}$ \\
\hline Work Experience 1 (WE1) & 6 & \multirow{4}{*}{$\begin{array}{l}\text { Formal course structure to match work experience } \\
\text { period. Each course of nominal } 12 \text { weeks duration. } \\
\text { Assessment limited to weekly activity and reflection } \\
\text { journals and self-established job objectives. }\end{array}$} \\
\hline Work Experience 2 (WE2) & 6 & \\
\hline Work Experience 3 (WE3) & 6 & \\
\hline Work Experience 4 (WE4) & 6 & \\
\hline
\end{tabular}

\section{The Courses}

Professional Practice Preparation 1 (PPP1) is designed to prepare the second year students for their first work placement. These students have 2 years of technical study, but need to be "work ready". The faculty recognized that if the students are in the workplace for only six - eight months, then they need to be of value to the employer from the start. In the same way that the technical study had been specifically chosen to ensure that they were capable of performing worthwhile engineering work, the professional practice course was designed to ensure that they were not lost in a professional environment. The course covers:

- Resume and letter writing skills

- Responding to selection criteria

- Interview techniques

- The transition from study to work 
- Employment contracts and conditions

- Identifying the industry and types of employer they hope to be involved with as an engineering practitioner

- How to evaluate their own work in terms of the Engineers Australia National Competencies

- Critical engineering workplace issues including ethics, codes of conduct and OHS.

Additionally the students attend the presentations given by the third year students who have just returned from their work placement. These presentations allow the students to hear what the actual placements were like. What the students gained from the experience? What were the conditions? What were the issues?

Professional Practice Review 1 (PPR1) is designed to have the students reflect on their first placement. They must describe their company, their department and their employment conditions. They must also give a description of the work that they ddi, what projects they were involved in and how the work was achieved. They are asked to reflect on their competence in the position. They must then reflect upon what was achieved by the work, and identify what contribution they made to the company, and the significance and value of the experience to themselves, as well as any specific learnings. They must do a self evaluation of their personal growth in the areas of intellectual, social and professional growth. This is not just identifying their growth, but articulating the change in themselves that demonstrates that the growth has occurred. Finally they must articulate and analyse the workplace issues that they had to deal with.

As part of demonstrating that they are addressing professional growth, they are asked to write a career episode report. This is a document that will form part of their engineering practice portfolio for application to become a Chartered Professional Engineer (CPEng).

Professional Practice Preparation 2 (PPP2) is taken by the fourth year students, preparing them for their second work placement, and follows on from PPP1. It has the students investigate:

- Their skills and attributes

- Professional responsibility

- Career exploration

- Career management

- Further interview skills

- Further review of Engineers Australia National Competencies for CPEng

Once again the students attend the presentations by the fifth year students returning from their second work placement.

Professional Practice Review 2 (PPR2) follows the same format as PPR1. The students reflect on their work placement and present their reflections to the class. This sharing of reflections allows the students to compare their experiences and identify common issues and share solutions that they have developed to those issues. Additionally they are asked to reflect on their career planning process, and to evaluate their ability to function in their chosen career. 
Work Placement courses consist of a formal course structure to match the work experience period. Each work experience consists of a nominal 26 weeks duration. Assessment is limited to weekly activity and reflection journals and self-established job objectives, along with an employer evaluation of their work during the placement.

\section{Conclusion}

A structured program to explicitly develop professional practice skills has been developed and implemented at CQUniversity. The original introduction of co-operative education was expected to enhance the development of generic skills in engineering graduates through the exposure to the work place. However, incorporating and integrating explicit professional practice skills development, has enabled a significant internalisation of professional practice. The professional practice skills addressed include intellectual, professional and social development. The internalisation occurs through identifiable preparation for, application in, and considered reflection of, learning experiences.

The professional practice program is similar to one offered at the University of Technology, Sydney, called a Diploma of Engineering Practice. (University of Technology, Sydney ${ }^{7}$ ). This means there are now two engineering faculties in Australia offering a dual award incorporating co-operative education and professional practice. This is evidence that there is an increasing perception amongst industry and educators that the professional practice skills require explicit development and recognition.

CQUniversity has developed a unique program with its integration of co-operative education, specific development and recognition of professional practice skills and a PBL curriculum.

\section{Bibliography}

1. IEAust, (1996). Changing the Culture: Engineering Education into the Future. Canberra: Institution of Engineers, Australia

2. King R (2008) Engineers for the Future Epping: Australian Council of Engineering Deans, Australia

3. Thom, D. (1998), Engineering education and the new industrial revolution. International Journal of Engineering Education, 14 (2). 89 - 94

4. Boeing Company and Rensselaer Polytechnic Institute (1997, January 22 - 23). A manifesto for global engineering education. Summary Report of the Engineering Futures Conference.

5. Jorgensen D., Howard P. (2005), Ten Years in the Making - A Unique Program in Engineering, Journal of Cooperative Education \& Internships $-14^{\text {th }}$ World Conference on Co-operative Education, World Association for Co-operative Education, June 2005 Boston USA

6. JGFEPS (2004a) Business Plan - Diploma of Professional Practice. Rockhampton: James Goldston Faculty of Engineering and Physical Systems, Central Queensland University

7. University of Technology, Sydney (2005). Retrieved March 29, 2005 from http://www.eng.uts.edu.au/ProspectiveStudents/undergraduate/bachelorofengineering.htm\#STRUCTURE 